\title{
On The Protection of the Lease Contract of the House
}

\author{
Chang-Yue Shen, Ling-Yun Zhang \\ Civil and Commercial Law, North China Electric Power University, Baoding, China \\ E-mail: a1518791223@qq.com
}

\begin{abstract}
With the development of our social economy, accelerating the process of the city, the urban population increased rapidly, the demand for housing is more and more strong. Housing rental industry through the integration of fragmented social housing, in order to promote the optimal allocation of housing, the housing rental has gradually become the main way to solve the problem of housing. The lease has become a more and more important in civil relations. Derived from the rental housing contradiction is becoming more and more prominent, the housing lease between the lessee in disadvantage, in order to maintain the harmony of people's livelihood and social stability, our country law expressly stipulated, give the lessee legal protection. This article tries to discuss the protection of the lease contract from the lessee's right of first refusal, the purchase and sale of the lease and the tenant's death, and so on.
\end{abstract}

Keywords-the right to lease; the right to purchase; and the sale do not break the lease; the problem of the lease contract to continue when with the tenant died

\section{INTRODUCTION}

It is more and more strong with the development of China's social economy, the acceleration of urbanization, the rapid growth of urban population, the demand for housing. Housing rental industry through the integration of fragmented social housing, in order to promote the optimal allocation of housing, the housing rental housing has gradually become the main way to solve the problem of housing. Leasing relationship becomes more and more important. It is becoming more and more prominent, derived from the rental housing contradiction, the housing lease between the lessee in disadvantage, in order to maintain the harmony of people's livelihood and social stability, our country law expressly stipulated, give the lessee legal protection.

Housing lease refers to by the owner or operator of housing will be its owned or operated by a housing to housing consumers use, housing consumers through regular delivery of a certain amount of rent, housing possession and use rights behavior. Rental housing is a commodity circulation housing value sporadic sale. Rent a party for rental housing, housing rent and the payment of a party to the lessee. The lessee has the following rights and interests:

The lessee shall have the right to possess, use, benefit and dispose of the leased house. Since the term of lease to the lessor shall housing will be transferred to the lessee possession and use, and the lessee has the right to obtain and maintain the housing possession until the lease term expires. During the lease term, the lessee right to exclude the lessor and the third person to share in the interference of the right; parties have not agreed on the application methods of the leased property, as long as according to the property itself is usually applicable methods and lossless in the interests of the lessor, the lessee can in any way make leasehold, the lessee people to lease the normal loss of irresponsible.[1] if the natural damage to the residential housing, but also require the timely repair of housing rental housing for non residential maintenance, according to the two sides in the lease contract agreement. 220th provisions of "contract law" in our country: "the lessor shall perform the obligations of maintenance of the lease item, except otherwise agreed by the parties."The 221st provision: "the lessee in the lease item may require maintenance of the lessor in a reasonable period of maintenance. If the lessor fails to perform the obligations of maintenance, the lessee may repair it by itself, and the maintenance cost shall be borne by the lessor. Because of the use of the maintenance effect, should reduce the rent or extend the lease" The right to dispose of the house. According to China's "general principles of the civil law" ninety-first provisions: "one side of the contract will be transferred to the rights and obligations of the contract to the third party, shall obtain the other party's consent contract, and not for profit" According to this argument, with the consent of the Lessor the lessee can be leased housing all or part of the leased to others. When the leased rent can be higher than the original lease rental sublet, people can obtain economic benefits from.

The lessee shall have the preemptive right and the right of priority to the leased building. If the lessor sells the leased house to the lessee, the lessee has the right of preemption in the same condition; and if the lessor continues to rent the house after the expiry of the lease, the lessee shall have the priority of the tenant.

\section{THE PROTECTION OF THE LEASE--RIGHT OF THE FIRST} REFUSAL

Housing tenant of preemptive right refers to the transfer of housing rental housing, the lessee in accordance with the law or in accordance with the contract and enjoy in all housing sold housing, under the same conditions, the pre emptive right of leased housing. The system originated very early, "German Civil Code" article 463 stipulates: "underlying's priority to buy authorized person, prior to sell obligor and the underlying material contracts, can exercise the preemptive right"; China's Taiwan region "land law" the 173rd stipulation: "the lessee the lessee priority priority right 
of buying for the lessee lessor of the sale contract claim." Preemptive right practice the principle of civil law and commercial law, fairness and justice, has a protective lease the positive significance of human rights: on the one hand the preemptive right in some extent admitted established social relationship, reduce unnecessary social disputes, played a role in the stability of social economic order; on the other hand, pre emptive rights identified can maximize the play the social and economic benefits of material wealth, using optimization methods, improve the use efficiency.[2] China's "contract law" the 230th stipulation: "the lessor sells the leased property shall be the lessee within a reasonable period of time before the sale notice, the lessee has the right of first refusal under the same conditions." The Supreme People's court "on the implementation of the < the people's Republic of China law rules on several issues opinion (Trial)" Article 118 stipulates: "the lessor sell rental housing, shall be three months in advance to inform the lessee, the lessee in the same conditions enjoy preferential buy right, the Lessor Not according to the provisions of the house sold, the lessee may request the people's court to declare null and void the sale of housing."

Law on the protection of the right to purchase the priority of the housing can be divided into two kinds of prior protection and post protection. You should first purchase the right to the formation of the right, the right to exercise their rights, only by their own means, does not have to say to the lessor. If the lessor is to sell the fact that the rental housing notice the lessee, the lessee is no priority to purchase. Therefore, the law provides that the lessor is obliged to inform the lessee of the fact that the house was sold. Notification procedure is the prior protection of the right of preemption. If lessor fails to perform its obligations, the lessee preemptive right in vain, the lessor should bear the corresponding responsibility; the lessor fails to notify the lessee, and the housing sold to a third of the people constitute to lease a violation of human rights, the lessee may the revocation of the right and right of claim for damage compensation, relief right of first refusal.[3] the lessee may request the court to revoke the contract for the sale of the lessor and the third person who has entered into force. But only guide the lessee preemptive right of existence in the third person, the lessee can exercise the right of revocation, if the third party does not know the preemptive right of existence, and the lessor conclude a contract for the sale of housing, lessee can not exercise the right of revocation, only to the lessor to claim compensation.

\section{THE PROTECTION OF THE RIGHT OF LEASE--BUYING AND SELLING IS NOT BROKEN LEASE}

In the course of the duration of the lease relationship, if the lease item is transferred or set the property right, the lessee shall claim the right to lease the lessee to obtain the ownership of the leased property or the person who has the right to property. The relevant provisions of the lease sale in [4] law. The German Civil Code "article 556 provides that:"
(1) rental housing to pay to the lessee, lessor assignment of the third person, instead of the lessor join yuan rental contract, bear corresponding rights and obligations. (2) if the Assignee does not perform its obligations, the lessor shall be liable for the loss of compensation for the assignee, and shall bear the same liability as the guarantor of the right to defend the right of defense."[4]France Civil Code 1743rd: if the lessor to sell the lease on third people, land or housing tenants can be notarized or have a certain period of time to fight the contract to fight against the buyer." In China in 2007, "property law" Article 19 stipulates that the mortgaged property has been leased prior to the "conclusion of the mortgage contract, the original lease is not affected by the impact of the mortgage right, mortgage after the establishment of mortgage of rental property, the lease relationship may not be used against the registered mortgage right."

The constant expansion of the principle of sale and purchase does not break the practical application. 1 the lease shall not break the lease, the lessee has the consent of the lessor, the house will be leased to his understanding of the right to lease the right to continue to exist; 2 mortgage does not break the lease, China's "security law" forty-eighth provisions: "the mortgage will have the property mortgaged, the original lease contract continues to be effective."Mr. Wang ZeJian think: "constitute an act of lease transfer, trade, reciprocity, gifts and bequests, even the partnership funded. Quasi by the eye, the so-called "business does not break the lease" is not accurate, strictly speaking, should be referred to as the ownership of the lease does not break". According to the actual situation, Mr. Wang Zejian's assignment does not break the lease is more accurate.

"The sale does not break lease" principle is all the people of new lease make interests of the necessary sacrifice, to safeguarding the lessee has enjoyed the right to lease, the lease relationship are not affected by the sale, assignment of the lease, the lessee can sustained and reasonably and fully use, with the use of property of the maximum social benefits of the lease.[5] at the same time, the existing lease relationship completely directly applicable to all the people of new lease, eliminates the respect other enter into a lease contract costs the costs and avoid the waste of resources and avoids the interruption of the lessee to lease the use and maintain the stability of social order, promote the steady, sustained and healthy economic activity.

\section{THE PROTECTION OF THE RIGHT OF LEASE--THE PROBLEM WITH THE CONTRACT OF HOUSING LEASE WHEN THE TENANT DEATH}

China's "contract law" 229th provisions "of the lease property changes in the lease period, does not affect the validity of the lease contract", that is, the sale does not break the lease. "Ownership change" is not only limited to the sale and purchase behavior, but also including the gift, the death of the lessor and the inheritance and so on.In order to clarify the death of the lessor lease continues to exist, whether or not to break the lease of the tenant to get rid of the theory of the lease. Some scholars believe that the lease contract has 
the characteristics of personality, in accordance with the provisions of the claims, the nature of the lease is not to be transferred from the creditor's rights."[6] other scholars believe that the lease contract shows great material characteristics, the lease contract is not based on the individual quality of the lessee, the main replacement does not necessarily affect the interests of the parties." so many scholars advocate the death of the lessee, the lease contract should not be terminated and the right to lease can be inherited.

There are two main types of housing lease contract when the tenant is dead: the lease contract with the center of the common living human being is continued and the lease contract that takes the human as the center continues to exist. China's "contract law" 234Th provisions: "the tenant in the housing lease period of death, and their living together before the original lease contract rental housing."According to this law, the common people can live in the lessee after the death of the tenant to inherit the right to lease the housing, the tenant of this kind of right is known as the right to inherit the lease. The common people are endowed with the right to take care of the legal relationship between the life of the common people and the stability of the contract. Living together with the tenant, the housing is an important evidence to maintain the relationship between life, if the lease contract with the lessee to die and the suspension is not moral. At the same time, although the lease contract, the lessee signed, but living together facts and lessee live together, have in fact of possession and use rights to the leasing of housing, give live together right is conducive to the stability of the legal relationship, for the lessor and live together, people have a positive role.In the housing lease contract, the lease right is regarded as a kind of property right which can be circulated. Such as the French Civil Code stipulated, in the death of the lessee, lease transfer to heirs, or transferred to totally summarize by a gift or part summarizes the legatee. Drawing lessons from other countries' advanced legislation, the law of our country can be improved from the following aspects: 1. Clearly defined public with people living in the area; 2. Clearly defined public inheritance with people living lease exercise period and exercise order; Clear public life with specific circumstances, increase management; 4. Increase the declaration of disappearance and death.

Lessee as a often occurs and the relationship between social and economic order and stability of real production of the main transaction modes, the law to deal with housing tenant enjoyed by the people of the housing lease to be further legal protection from the legislation, to the lessee of the legitimate rights and interests can be effectively realized.

\section{ACKNOWLEDGEMENT}

Central Universities Fundamental Research Project Support, Project Finance Number9161214009.

\section{REFERENCE}

[1]. Zhou Li , "The legal protection of the right of the house tenant", Management and Administration, pp56-57, Jul. 2007.

[2]. Wen Haimin, "The analysis of the case of the priority of lease contract", Master Thesis of Hunan University.

[3]. Xu Yunyong, "Study on the protection of the rights and interests of the lessee in house leasing", Master Thesis of Sichuan University.

[4]. Liu Xuemei, "On the principle of not breaking the lease", Sichuan University Master's Degree Thesis.

[5]. Lin Lan, "On the lessee protection system by not breaking the sale of lease and preemptive right as the center", Journal of Nanjing University.

[6]. Tension, Zheng Zhifeng, "Study on the existing problems of housing lease contract during the death of the tenant", Law, 2014. 